\title{
PERAN DAN KOMPETENSI AUDITOR SYARIAH DALAM MENUNJANG KINERJA PERBANKAN SYARIAH
}

\author{
Aulia Putri Oktaviani Jusri, Erina Maulidha \\ Sekolah Tinggi Ekonomi Islam SEBI, Depok, Indonesia \\ auliaputrioktavianiyusri@gmail.com, erina.maulidha@sebi.ac.id \\ https://doi.org/10.46367/jas.v4i2.255 \\ Received: Nov 07, 2020 Revised: Dec 03, 2020 Accepted: Dec 08, 2020 Published: Dec 16, 2020
}

\begin{abstract}
The increase in the growth of Islamic banking needs to be supported by the performance of sharia auditors. This study aims to discuss the role and competence of Islamic auditors in supporting the performance of Islamic banking. This type of research uses qualitative methods with a descriptive approach using literature study data. The results of this study indicate that the competencies that must be possessed by sharia auditors include knowledge of Islamic law, fiqh muamalah, skills in accounting and auditing, and special characteristics as sharia auditors. This competence is the key to maximizing the role and competence of sharia auditors to support the performance of Islamic banking. The roles of sharia auditors include as independent auditors, internal auditors, and sharia supervisory board. Sharia compliance tests on Islamic financial institutions are part of the role of the sharia auditor.
\end{abstract}

Keywords: Role of Sharia Auditors, Competence of Sharia Auditors, Sharia Banking Performance

\begin{abstract}
ABSTRAK
Kenaikan pertumbuhan perbankan syariah perlu didukung dengan kinerja dan keberadaan auditor syariah. Penelitian ini bertujuan untuk membahas peran dan kompetensi auditor syariah dalam mendukung kinerja perbankan syariah. Jenis penelitian ini menggunakan metode kualitatif, pendekatan deskriptif dengan data studi pustaka. Hasil penelitian ini menunjukkan bahwa kompetensi yang harus dimiliki oleh auditor syariah meliputi pengetahuan hukum Islam, fiqh muamalah, keterampilan di bidang akuntansi dan audit, serta karakteristik khusus sebagai auditor syariah. Kompetensi tersebut menjadi kunci untuk memaksimalkan peran dan kompetensi auditor syariah dalam menunjang kinerja Perbankan Syariah. Peran auditor syariah mencakup auditor independen, auditor internal, dan dewan pengawas syariah. Uji kepatuhan syariah pada entitas Lembaga Keuangan Islam menjadi bagian dari peran auditor syariah.
\end{abstract}

Kata Kunci: Peran Auditor Syariah, Kompetensi Auditor Syariah, Kinerja Perbankan Syariah 


\section{PENDAHULUAN}

Secara umum lembaga keuangan syariah dan konvesional dapat dikatakan memiliki fungsi yang sama, yaitu menghimpun dana dari masyarakat dan mengelolanya dalam bentuk penyertaan modal, asuransi, leasing dan sebagainya. Akan tetapi dalam beberapa hal, lembaga keuangan syariah memiliki perlakuan yang berbeda karena transaksi yang berlaku dalam lembaga keuangan syariah sangat khusus jika dibandingkan dengan lembaga keuangan konvensional (Umam 2015). Salah satunya, adanya jaminan bahwa apa yang mereka jalankan sudah sesuai dengan pemenuhan syariat Islam dan adanya keyakinan bahwa apa yang telah dilakukan tidak melanggar prinsip syariah (Ardi 2017).

Sektor ekonomi pada bidang perbankan syariah di Indonesia dimulai dengan lahirnya Bank Muamalat Indonesia tahun 1992. Kemudian, setelah krisis ekonomi pada tahun 1998, lahirlah perbankan syariah selanjutnya yaitu Bank Syariah Mandiri. Selanjutnya berturut-turut hadir beberapa Undang-Undang (UU) sebagai bentuk dukungan pemerintah terhadap kemajuan aplikasi ekonomi Islam di Indonesia. Konsep keuangan berbasis syariah Islam telah diterima secara luas di dunia dan menjadi alternatif baik bagi pasar yang menghendaki kepatuhan syariah (syariah compliance), ataupun bagi pasar konvensional sebagai sumber keuntungan (profit source) (Fauzi and Supandi 2019).

Tumbuh pesatnya industri keuangan syariah ditandai dengan meningkatnya jumlah lembaga keuangan yang mendirikan ataupun membentuk unit usaha berbasis syariah dari tahun ke tahun. Menurut data Otoritas Jasa Keuangan (2020), sampai Juni 2019 jumlah bank syariah di Indonesia berjumlah 189 bank syariah yang terdiri dari 14 Bank Umum Syariah (BUS), 164 Bank Pembiayaan Rakyat Syariah (BPRS), dan 20 Unit Usaha Syariah (UUS). Berikut ini gambarannya jika ditampilkan melalui Gambar 1.

\section{Gambar 1 Perkembangan Jumlah Lembaga Keuangan Syariah di Indonesia}

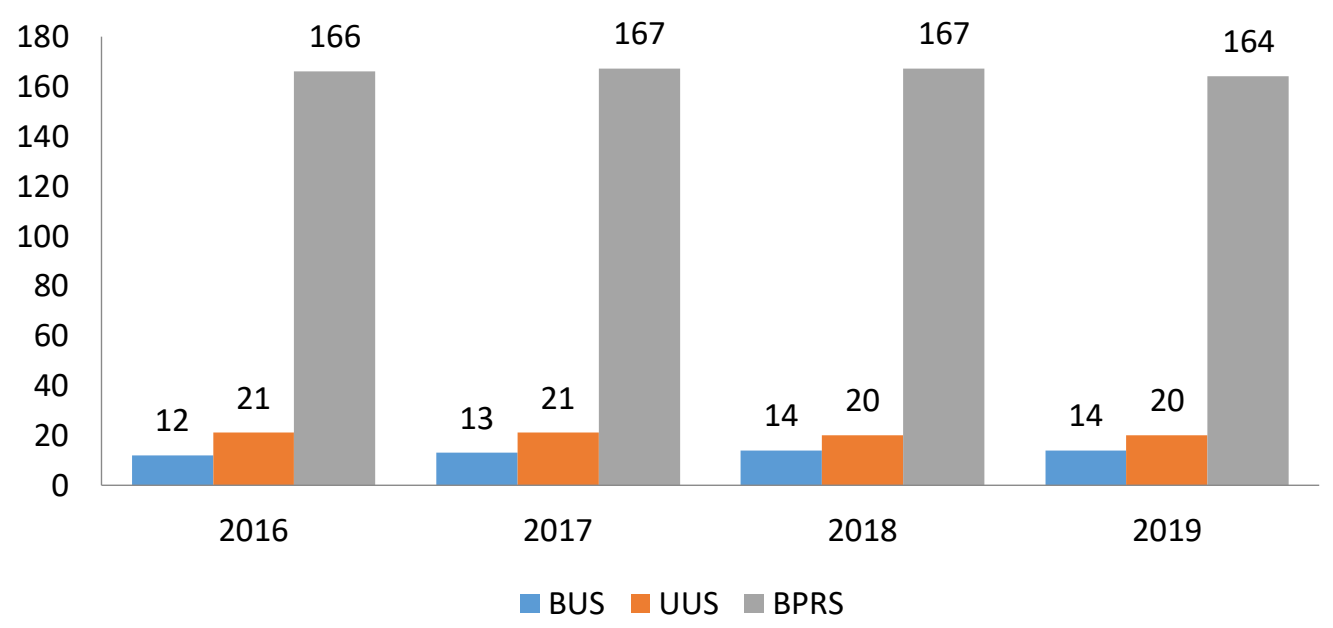

Sumber: Statistik Perbankan Syariah OJK tahun 2020 (diolah)

Jika dilihat dari keseluruhan aset, BUS dan UUS memiliki total aset sebesar 524,564 miliar rupiah, sedangkan BPRS memiliki total aset sebesar 13,758 miliar rupiah. Angka tersebut menunjukkan peningkatan bila dibandingkan dengan data tahun 2016. Pada bulan Juli tahun 2016, jumlah aset BUS dan UUS 
masih berkisar pada 356,504 miliar rupiah dan total aset BPRS sebesar 9,157 miliar rupiah. Berdasarkan survei Index Islamic Finance, dari 36 negara yang disurvei dalam Islamic Finance Country, posisi Indonesia berada di peringkat 4, di bawah Iran, Malaysia, dan Saudi Arabia. Bahkan, Indonesia di atas Bahrain dan Inggris (Mardian 2015).

Seiring dengan pertumbuhan kepercayaan masyarakat kepada lembaga keuangan syariah, maka lembaga keuangan syariah perlu untuk mempertahankan dan meningkatkan konsistensi penerapan prinsip syariah. Karena dari hasil penelitian oleh Bank Indonesia menyatakan bahwa nasabah yang menggunakan jasa bank syariah, sebagian memiliki kecenderungan untuk berhenti menjadi nasabah antara lain karena keraguan akan konsistensi penerapan prinsip syariah. Sehingga pemenuhan prinsip syariah oleh pengelola bank syariah dibutuhkan untuk menumbuhkan kepercayaan seluruh stakeholder (Wardayati 2011).

Luasnya ruang lingkup audit syariah mengakibatkan auditor syariah tidak hanya memiliki kewajiban untuk memeriksa kewajaran dalam laporan keuangan Lembaga Keuangan Syariah (LKS), melainkan juga harus memeriksa kesesuaian LKS terhadap prinsip syariah yang berlaku, sehingga diperlukan adanya auditor syariah yang memiliki kompetensi dalam bidang keuangan/auditing dan syariah. Di Indonesia sendiri, kebutuhan akan uji kompetensi bagi auditor syariah ini difasilitasi oleh Ikatan Akuntan Indonesia (IAI) (Dewi and Sawarjuwono 2019).

Sebagai organisasi profesi akuntan, IAI menyediakan Sertifikasi Akuntansi Syariah (SAS) bagi auditor syariah, namun sertifikasi yang ada ini dirasa masih belum optimal karena materi dalam SAS belum mencakup konsep dasar dan proses audit syariah seperti yang diterapkan oleh lembaga sertifikasi atau pelatihan auditor syariah di beberapa negara yang telah memiliki auditor syariah. Selain itu, terdapat tantangan dalam penerapan audit syariah. Setidaknya ada empat faktor yang menjadi kendala besar dalam penerapan audit yang berdasarkan hukum syariah, yaitu: kerangka kerja; ruang lingkup; kualifiasi; dan isu terkait independensi (Mardiyah and Mardian 2015).

Audit syariah menjadi salah satu cara untuk menjaga dan memastikan integritas lembaga keuangan syariah dalam menjalankan prinsip syariah. Audit syariah dapat memberikan assurance kepada stakeholder serta sangat dibutuhkan untuk merespon perkembangan industri keuangan syariah yang cepat ini. Apabila terjadi kegagalan dalam audit syariah, akan berdampak buruk bahkan menyebabkan kegagalan dalam pemenuhan prinsip syariah itu sendiri (Akbar et al. 2015).

Salah satunya, kasus terkait kinerja perbankan syariah yang terjadi pada Bank Mandiri Syariah dan BNI Divisi Usaha yang memperoleh bunga sebesar 19\% karena terlibat dalam proyek sindikasi Indosat Multimedia Mobile (IM3) adalah bukti lemahnya penerapan audit syariah melalui peran komite audit, dewan pengawas syariah (DPS) dan internal kontrolnya (Fauzi and Supandi 2019).

Untuk mendukung kinerja perbankan syariah, diperlukan adanya auditor syariah yang kompeten. Ketidaksesuaian antara harapan dan realita yang terjadi karena belum memadainya pemahaman auditor syariah yang terlihat dari audit syariah yang hanya difungsikan sebagai pelengkap dari audit keuangan (seperti yang tertuang dalam Tabel 1). Selain itu, juga belum ditemukan opini dari audit syariah seperti layaknya audit keuangan dari auditor independen. Hal ini tidak hanya terjadi di Indonesia saja. Salah satunya, Malaysia juga mempunyai masalah 
yang sama, yaitu kurangnya SDM dan kompetensi auditor syariah yang memadai. Hanya 5,9\% dari total responden yang memiliki kedua kompetensi tersebut pada saat bersamaan (Izzatika and Lubis 2016).

Tabel 1 Data SDM Auditor Syariah di Indonesia

\begin{tabular}{clr}
\hline No. & \multicolumn{1}{c}{ Keterangan } & Jumlah \\
\hline 1 & Pengurus DSN MUI di Bidang Perbankan Syariah & 7 orang \\
2 & Akuntan Publik di Bidang Perbankan Syariah pada & 145 orang \\
3 & Kantor Akuntan Publik berdasarkan data OJK & 2.163 orang \\
4 & Auditor bersertifikat CPA IAPI & 346 orang \\
5 & Auditor bersertifikat CA IAI & 97 orang \\
\hline Sumber: Dari berbagai sumber tahun 2020 (diolah)
\end{tabular}

Sumber: Dari berbagai sumber tahun 2020 (diolah)

Berdasarkan Tabel 1, dapat dijelaskan bahwa auditor di bidang akuntan publik pada perbankan syariah terdapat 145 orang dari 2.163 orang yang bersertifikat CPA IAPI dan 346 orang bersertifikat CA IAI. Sedangkan, auditor yang memiliki sertifikat di bidang syariah hanya ada 97 orang. Jika dibandingkan dengan data perbankan syariah hingga Juni 2019 ada 189 bank. Hal ini memiliki ketimpangan antara jumlah bank syariah yang ada dengan SDM di bidang auditor syariah. Karena kurangnya auditor syariah yang dapat memenuhi kebutuhan industri yang tergambar dari sedikitnya jumlah auditor syariah di Indonesia mengakibatkan rangkap jabatan dilakukan oleh dimana auditor syariah bekerja pada beberapa lembaga keuangan syariah pada periode yang sama.

Auditor yang bersertifikat syariah tak hanya menangani di bidang perbankan syariah saja melainkan di bidang lembaga syariah lainnya. Idealnya auditor syariah memerlukan auditor yang bersertifikat syariah sejumlah perbankan yang ada. Artinya masih sekitar 92 orang lagi yang belum memiliki sertifikasi syariah. Di Indonesia memang diperbolehkan auditor syariah bekerja untuk 4-5 lembaga keuangan syariah, namun rangkap jabatan pada lebih dari satu institusi lembaga keuangan syariah dapat memicu konflik kepentingan dan dapat memungkinkan mengganggu obyektivitas dalam menjalankan kesesuaian syariah (Izzatika and Lubis 2016).

Dengan adanya auditor syariah dalam perbankan syariah peran auditor syariah sangat penting dalam menunjang sebuah bank untuk berkembang dan memiliki kinerja yang baik sehingga bank tersebut bisa melakukan praktik syariah yang sesuai dengan prinsip-prinsip syariah yang berlaku. Untuk itu penelitian ini bertujuan untuk membahas peran dan kompetensi auditor syariah dalam mendukung kinerja perbankan syariah.

\section{TELAAH LITERATUR}

\section{Bank Syariah}

Bank Syariah menjadi salah satu bagian dari Lembaga Keuangan Syariah (LKS) yang memiliki karakteristik berbeda dengan entitas konvensional (Ardi 2017). Menurut Munawir (2005), sejarah berdirinya perbankan dengan sistem bagi hasil (lebih dikenal dengan istilah Bank Syariah) didasarkan pada dua alasan utama yaitu: (1) Adanya pandangan bahwa bunga bank (interest) pada bank 
konvensional hukumnya haram karena termasuk kategori riba yang dilarang dalam agama, bukan saja oleh Islam tapi juga oleh agama Samawi lainnya. (2) Dari aspek ekonomi, penyerahan risiko usaha terhadap salah satu pihak dinilai melanggar norma keadilan.

Kebutuhan atas pemenuhan syariah ini mendorong munculnya fungsi audit baru yakni audit syariah. Audit syariah memiliki ruang lingkup lebih luas daripada audit konvensional karena audit syariah digunakan untuk memastikan produk, jasa, dan semua kegiatan yang dilakukan Lembaga Keuangan Syariah (LKS) telah sesuai, adil dan relevan dengan prinsip syariah (Yaacob and Donglah 2012).

\section{Auditing Dalam Perspektif Syariah dan Prinsipnya}

Kebenaran atas catatan keuangan merupakan hal yang juga diharuskan oleh Allah SWT dimana tidak boleh ada kelebihan maupun kekurangan atas angka transaksi yang sebenarnya. Pemeriksaan atas catatan transaksi keuangan dalam akuntansi disebut sebagai auditing. Praktik terkait pentingnya proses auditing juga terdapat dalam Al-Qur'an yang berbunyi:

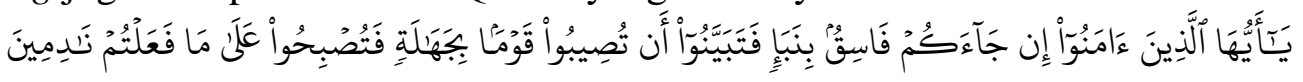

Artinya: "Hai orang-orang yang beriman, jika datang kepadamu orang fasik membawa suatu berita, maka periksalah dengan teliti, agar kamu tidak menimpakan suatu musibah kepada suatu kaum tanpa mengetahui keadaannya yang menyebabkan kamu menyesal atas perbuatan itu”. (QS. Al-Hujurat [49]:6).

Berdasarkan ayat tersebut kita dapat memetik pelajaran bahwa pemeriksaan atas laporan keuangan merupakan hal yang patut dilaksanakan untuk menjamin kebenaran atas laporan keuangan tersebut dan tidak merugikan atau menimbulkan musibah bagi pihak yang menggunakan informasi atas laporan keuangan tersebut. Dengan adanya anjuran tersebut maka perkembangan ilmu dan kebijakan modern membawa adanya kewajiban untuk perusahaan terbuka untuk memberikan jaminan kepada stakeholder terkait kehandalan laporan keuangan melalui proses pemeriksaan atau auditing (Nuha 2017).

Menurut Shafii et al. (2013), auditing dalam Islam adalah: (a) proses menghitung, memeriksa dan memonitor (proses sistematis); (b) tindakan seseorang (pekerjaan duniawi atau amal ibadah; lengkap dan sesuai syariah; (c) untuk mendapat reward dari Allah di akhirat.

\section{Auditor Syariah}

Istilah auditor syariah digunakan untuk menyesuaikan dengan operasional entitas syariah karena proses audit dilakukan tidak hanya sesuai dengan standar regulasi tetapi juga sesuai dengan prinsip syariah (Mardiyah and Mardian 2015). Maka apabila terjadi kegagalan dalam audit syariah, akan berdampak buruk bahkan menyebabkan kegagalan dalam pemenuhan prinsip syariah itu sendiri. Adapun saat ini yang berperan sebagai auditor syariah ialah DPS, auditor internal dan auditor eksternal (Mardiyah and Mardian 2015).

Dalam audit konvensional, ruang lingkup audit jelas dinyatakan sebagai pedoman bagi auditor untuk bersikap objektif dalam pengumpulan bukti mereka. Jika tidak, penugasan audit akan menjadi lebih lama dan sumber daya seperti waktu dan uang yang terbuang karena tidak ada ruang lingkup yang jelas untuk pekerjaan audit. Audit syariah diklaim sebagai fungsi sosial. Oleh karena itu, ruang lingkup harus lebih luas meliputi perilaku sosial dan kinerja organisasi 
termasuk hubungan mereka dengan semua pemangku kepentingan (Yaacob and Donglah 2012).

Ruang lingkup auditor syariah terdiri dari: (1) Ruang lingkup sebagai auditor independen. Auditor independen merupakan suatu akuntan publik yang bersertifikat atau kantor akuntan publik yang melakukan audit atas entitas keuangan komersial maupun non-kormersial. Profesi akuntan publik bertanggung jawab untuk memberikan penilaian atas kewajaran dari laporan keuangan perusahaan, sehingga masyarakat pada umumnya, dan para pelaku bisnis pada khususnya, memperoleh infomasi keuangan yang andal sebagai dasar memutuskan alokasi sumber-sumber ekonomi. Seorang akuntan juga bertanggung jawab apabila terjadi manipulasi-manipulasi keuangan (Carolita and Rahardjo 2012). (2) Ruang lingkup sebagai Sharia Compliance. Kepatuhan syariah dalam operasional bank syariah tidak hanya meliputi produk saja, akan tetapi meliputi sistem, teknik dan identitas perusahaan. Karena itu, budaya perusahaan yang meliputi pakaian, dekorasi dan image perusahaan merupakan salah satu aspek kepatuhan syariah dalam bank syariah. Tujuannya, tidak lain untuk menciptakan suatu moralitas dan spiritual kolektif, yang apabila digabungkan dengan produksi barang dan jasa, maka bisa menopang kemajuan dan pertumbuhan jalan hidup yang Islami (Mulazid 2016). (3) Ruang lingkup sebagai audit internal. Fungsi audit internal menurut Suginam (2017), merupakan kegiatan yang bebas, yang terdapat dalam organisasi, yang dilakukan dengan cara memeriksa akuntansi, keuangan, dan kegiatan lain, untuk memberikan jasa bagi manajemen dalam melaksanakan tanggung jawab mereka dengan cara menyajikan analisis, penilaian, rekomendasi dan komentar-komentar penting terhadap kegiatan manajemen. (4) Ruang Lingkup Dewan Pengawas Syariah (DPS).

Dewan Pengawas Syariah menurut Prabowo and Jamal (2017), memiliki peranan yang amat penting dalam perbankan syariah selaras dengan kontrak syariah yaitu: (a) Membuat pedoman persetujuan produk dan opersional perbankan syariah berdasarkan ketentuan yang telah disusun oleh Dewan Syariah Nasional (DSN); (b) Membuat laporan secara rutin pada setiap tahun tentang bank syariah yang berada dalam pengawasannya bahwa bank yang diawasinya telah berjalan sesuai dengan ketentuan syariah. Dalam laporan tahunan (annual report) institusi syariah, maka laporan dari DPS mesti dibuat dengan jelas; (c) Dewan Pengawas Syariah hendaklah membuat suatu laporan kepada pembangunan dan aplikasi sistem keuangan syariah di institusi keuangan syariah khususnya bankbank syariah yang berada dalam pengawasan, sekurang-kurangnya enam bulan sekali. Laporan telah diberikan kepada Bank Indonesia terletak di ibukota propinsi dan atau Bank Indonesia di Ibu Kota Negara Indonesia, Jakarta; (d) Dewan Pengawas Syariah juga bertanggungjawab untuk mengkaji dan membuat usulan jika terdapat produk baru inovasi dari bank yang diawasinya. Majelis ini menjalankan penilaian awal sebelum produk yang baru dari bank syariah yang diusulkan itu sekali lagi diperiksa dan difatwakan oleh DSN; (e) Membantu sosialisasi syariah institusi keuangan perbankan/kepada masyarakat; (f) Memberi input untuk pembangunan dan kemajuan institusi keuangan syariah.

Melihat ruang lingkup audit syariah yang lebih luas dibandingkan dengan audit konvensional, maka auditor syariah tidak hanya berfungsi memastikan kewajaran laporan keuangan, tetapi juga harus dapat memeriksa kesesuaian dalam 
prinsip syariah (Dewi and Suwarjuwono 2019). Maka diperlukan kompetensi auditor syariah yang lebih komprehensif.

Menurut Riani and Mardian (2017), kompetensi auditor adalah kemampuan auditor untuk menemukan kesalahan sistem akuntansi keuangan kliennya. Dalam pengauditan, seorang auditor harus melaksanakan jasa profesionalnya dengan kehati-hatian, kompetensi dan ketekunan, serta auditor harus mempertahankan sikap kompetennya. Kompetensi teknis seorang auditor yang melaksanakan audit ditentukan oleh tiga faktor yaitu: (1) Pendidikan formal dalam bidang akuntansi di suatu perguruan tinggi termasuk ujian profesi auditor. (2) Pelatihan yang bersifat praktis dan pengalaman dalam bidang auditing. (3) Pendidikan professional yang berkelanjutan selama menekuni karier auditor professional.

Auditor syariah dituntut memiliki dua kompetensi sekaligus yakni kompetensi dalam bidang akuntansi dan audit syariah. Menurut Dewi and Sawarjuwono (2019), auditor harus memiliki pengetahuan dalam bidang syariah. Selain harus memiliki kemampuan akuntansi dan audit yang kompeten, auditor syariah juga harus mampu melakukan uji kepatuhan syariah terhadap LKS.

Bukan hanya itu, auditor juga dituntut untuk memahami standar akuntansi internasional yang diadopsi dengan standar akuntansi dan audit yang berlaku di wilayah nasional, serta standar akuntansi dan audit yang digunakan oleh negaranegara yang menerapkan audit syariah, sebab hal tersebut dibutuhkan untuk merumuskan opini (Izzatika and Lubis 2016).

Nawal et al. (2009), mengungkapkan: "In view of the drastic growth of Islamic institutions all over the world, in particular, the IFIs, this paper examines whether the current practice of shariah auditing in IFIs is in line with what is desired by Muslims". Maksudnya selama ini, auditor syariah masih dinilai belum memiliki kompetensi yang mumpuni, karena masih sedikit auditor yang memiliki kompetensi dalam dua bidang yaitu di bidang akuntansi dan audit syariah.

Kurangnya kompetensi pada dua bidang, akuntansi dan audit syariah, membuat kebutuhan akan auditor syariah menjadi sangat krusial (Putri and Hidayati 2019). Tidak seimbangnya kompetensi di bidang keuangan dan akuntansi dengan bidang syariah, sertifikasi yang belum optimal, dan minimnya lembaga pendidikan serta pelatihan yang menyediakan kurikulum akuntansi/audit syariah memengaruhi minimnya auditor syariah yang kompeten di Indonesia (Izzatika and Lubis 2016).

Berkaitan dengan kompetensi auditor syariah, masih terdapat ketimpangan kompetensi antara syariah dan akuntansi. Di Indonesia auditor yang memiliki sertifikasi di bidang syariah ada sekitar 97 orang dengan jumlah bank syariah sebanyak 189. Jumlah ini tentu saja tidak sebanding dengan kebutuhan akan auditor syariah di Indonesia. Bukan hanya dari sisi kuantitas, kualitas auditor syariah pun masih belum memadai. Kualifikasi auditor syariah selalu dipertanyakan karena belum adanya suatu lembaga khusus yang menyediakan program sertifikasi bagi auditor syariah. Padahal, sertifikasi merupakan hal krusial karena dapat menjadi tolak ukur kompetensi yang dimiliki oleh auditor syariah. Jika auditor syariah yang melakukan penugasan audit pada LKS tidak memenuhi kualifikasi, maka akan menyebabkan tidak optimalnya proses audit, sehingga menghasilkan laporan audit yang tidak relevan dalam mengungkapkan kepatuhan syariah sebuah LKS (Dewi and Sawarjuwono 2019). 
Secara umum peran auditor dalam sikap independensi dan tanggung jawab sangat diperhatikan oleh masyarakat, dalam tugasnya memeriksa laporan keuangan perusahaan, auditor dituntut untuk bersikap profesional yang akan memberikan pendapatnya sesuai dengan kenyataan yang ditemuinya selama audit berlangsung. Kejujuran, handal, mempertahankan etika, komitmen adalah beberapa ciri dari seorang professional akuntan dan auditor (Jesika et al. 2015).

Independensi mengandung unsur kemandirian dari dominasi pihak lain dan obyektifitas dalam melaksanakan tugas dan kewajibannya. Dalam hubungan dengan asas independensi (independency), Lembaga harus dikelola secara independen agar masing-masing organ perusahaan beserta seluruh jajaran di bawahnya tidak saling mendominasi dan tidak dapat diintervensi oleh pihak manapun yang dapat mempengaruhi obyektivitas dan profesionalisme dalam melaksanakan tugas dan tanggung jawabnya. Adanya transparansi (kejujuran) ditujukan bukan hanya untuk orang lain tetapi juga untuk diri kita sendiri. Agar semua kegiatan yang dilakukan terhindar dari benturan kepentingan dari berbagai pihak (Putri and Hidayati 2019). Tanggung jawab auditor terhadap pelaksanakan pemeriksaan dilakukan sesuai dengan norma profesi dan pelaporan temuannya, agar auditor memberikan opini audit yang dapat (Jesika et al. 2015).

Selain peran auditor tersebut, menurut Mardiyah and Mardian (2015) auditor syariah juga memiliki peran tambahan yakni: (a) DPS memiliki fungsi untuk merumuskan kebijakan dan pedoman yang harus diikuti oleh manajemen dalam melakukan kegiatan bisnis serta memberikan persetujuan atas produk yang akan dikeluarkan dan melakukan penilaian syariah. (b) Auditor internal dapat menjalankan fungsi audit syariah yang bertujuan untuk memastikan bahwa pengendalian internal telah berjalan dengan baik dan sesuai dengan prinsip syariah. Sedangkan Auditor eksternal memiliki peran yang unik dalam audit syariah, bukan hanya berperan dalam melakukan audit keuangan melainkan juga melakukan shariah compliance test untuk memastikan kepatuhan syariah dari perusahaan atau LKS.

\section{PEMBAHASAN}

\section{Urgensi Peran Auditor Syariah Untuk Menunjang Kinerja Bank Syariah}

Bank Syariah menjadi bagian dari Lembaga Keuangan Syariah (LKS) yang memiliki karakteristik berbeda dengan entitas konvensional. Perbedaan karakter ini mempengaruhi bentuk dan standar dalam kegiatan pengawasan lembaga bank syariah termasuk pelaksanaan auditnya (Minarni, 2013).

Yacob and Donglah (2012) menyatakan adanya kebutuhan pemenuhan aspek syariah ini mendorong munculnya fungsi audit syariah. Akbar et al. (2015) mengatakan bahwa audit syariah dapat memberikan assurance kepada stakeholders serta sangat dibutuhkan untuk merespon perkembangan industry keuangan syariah. Maka apabila terjadi kegagalan dalam audit syariah, akan berdampak buruk bahkan menyebabkan kegagalan dalam pemenuhan prinsip syariah itu sendiri. 
Tabel 2 Perbedaan Audit Syariah dan Audit Konvensional

\begin{tabular}{cll}
\hline No & \multicolumn{1}{c}{ Audit Syariah } & \multicolumn{1}{c}{ Audit Konvensional } \\
\hline 1. & $\begin{array}{l}\text { Obyeknya semua lembaga bisnis } \\
\text { baik itu, bank atau non bank yang } \\
\text { beroperasi dengan prinsip syariah }\end{array}$ & $\begin{array}{l}\text { Obyeknya semua lembaga bisnis baik } \\
\text { itu, bank atau non-bank yang tidak } \\
\text { beroperasi berdasarkan prinsip } \\
\text { syariah }\end{array}$ \\
2. & Mengharuskan adanya peran DPS & Tidak ada peran DPS \\
3. & Audit dilakukan oleh Auditor \\
bersertifikasi SAS (Sertifikat & Tanpa ketentuan bersertifikasi SAS \\
Akuntansi Syariah) & \\
4. Standar audit AAOIFI & Opini berisi tentang shari'a & $\begin{array}{l}\text { Standar auditing IAI } \\
\text { Opini berisi tentang kewajaran atau }\end{array}$ \\
& compliance atau tidak & Keuangan Perusahaan \\
\hline
\end{tabular}

Sumber: Minarni (2013)

Masalah yang ada dalam audit syariah di Indonesia adalah pertama auditor syariah jumlahnya terbatas, karena lembaga penyuplai SDM berkualitas belum mampu memenuhi kebutuhan industri. Salah satu penyebabnya adalah adanya timelag yang panjang, dimana industri membutuhkan SDM dalam waktu yang singkat, sedangkan lembaga penyuplai SDM (Lembaga Pendidikan) membutuhkan waktu yang panjang untuk menyiapkan SDM yang dibutuhkan (Febrian 2019). Berdasarkan data Ikatan Akuntan Indonesia tahun 2020 hanya ada sekitar 97 orang yang memiliki sertifikat pendidikan/pelatihan di bidang syariah. Sedangkan berdasarkan data Statistik Perbankan Syariah dari OJK, pertumbuhan Lembaga keuangan syariah terkhusus bank syariah hingga Juni 2019 di Indonesia berjumlah 189 bank syariah yang terdiri dari 14 Bank Umum Syariah (BUS), 164 Bank Pembiayaan Rakyat Syariah (BPRS), dan 20 Unit Usaha Syariah (UUS). Hal ini tidak seimbang antara kapasitas auditor syariah dengan industri syariah yang ada. Kedua, auditor yang disediakan lembaga penyuplai SDM dengan auditor yang dibutuhkan industri mengalami mis-match kualifikasi. Idealnya seorang auditor syariah memiliki kompetensi yang integrative antara pengetahuan umum, syariah, dan bisnis industri kontemporer. Sehingga saat ini yang mengaudit Laporan Keuangan (audit umum) adalah auditor umum dan yang di sisi syariah adalah Dewan Pengawas Syariah (DPS). Dalam praktiknya audit syariah sekaligus pengawasan audit syariah di Indonesia masih sebagai pelengkap dari proses audit dikarenakan audit syariah masih menjadi tanggung jawab Dewan Pengawas Syariah (DPS) bukan auditor syariah (Febrian 2019).

\section{Isu Auditor Syariah}

Apabila dilihat secara terpisah dan mendalam sumber permasalahan audit syariah yaitu diprioritaskan pada aspek kompetensi dan peran auditor syariah, karena melihat betapa beratnya baik ditinjau secara moril maupun materil maka sebaiknya audit harus dilakukan oleh seorang yang kompeten dan independen. Kefasihan pada bahasa Arab dan Inggris serta pemahaman dengan pengetahuan yang baik dalam syariah, fiqh muamalah, akuntansi, keuangan, audit dan bisnis dapat membantu auditor syariah dalam meningkatkan kompetensinya dan meningkatkan pemahaman terhadap kepatuhan syariah. Ia berpendapat bahwa 
karena lembaga keuangan syariah beroperasi di bawah platform yang berbeda yaitu dengan pandangan dunia Islam, mereka mungkin memerlukan berbagai jenis akuntansi dan audit yang berbeda (Izzatika and Lubis 2016).

Ketimpangan kompetensi ini juga ditemukan oleh Hood and Bucheery (1999) di Bahrain yang dikutip oleh (Shafii et al. 2013), penelitian tersebut menemukan bahwa ketidaksesuaian antara harapan dan realita yang terjadi karena belum memadainya kompetensi auditor syariah yang terlihat dari audit syariah yang hanya difungsikan sebagai pelengkap dari audit keuangan. Selain itu, juga belum ditemukan opini dari audit syariah seperti layaknya audit keuangan dari auditor independen.

Di Indonesia sendiri, praktisi audit di Indonesia ini masih mencari pedoman aturan yang tepat, regulasi kerangka kerja, serta kompetensi dan independensi auditor syariah (Shafii et al. 2013). Pendapat tersebut didukung oleh penelitian Akbar et al. (2015), bahwa ada dua permasalahan terkait kompetensi auditor syariah, pertama dari sisi kualitas yaitu tidak seimbangnya kompetensi auditor syariah dalam pengetahuan akuntansi dan syariah. Kedua, dari sisi kuantitas yaitu masih terbatasnya jumlah auditor syariah yang dimiliki oleh Indonesia. Sebagai negara dengan mayoritas penduduknya adalah muslim, jumlah auditor syariah yang dimiliki masih sangat terbatas.

Dengan demikian, hal tersebut menjadi permasalahan dan tantangan yang serius bagi auditor syariah khususnya dewan pengawas syariah di Indonesia. Belum lagi jika ditinjau dari segi keilmuan kompetensi yang harus dimiliki oleh auditor syariah berbeda dengan auditor pada umumnya karena auditor harus mengkombinasikan aspek keuangan dan aspek syariah dari operasional perusahaan.

\section{Opini Makna Auditor dan Audit Syariah}

Indonesia memiliki dualisme sistem ekonomi yaitu sistem ekonomi konvensional dan sistem ekonomi syariah, untuk itu, dalam menunjang kemajuan perkonomian syariah diperlukan lembaga audit syariah yang independen atau berdiri sendiri seperti lembaga audit konvensional. Sebut saja lembaga jasa audit milik swasta ataupun pemerintah seperti Kantor Akuntan Publik (KAP), Badan Pemeriksa Keuangan (BPK), dan Otoritas Jasa Keuangan (OJK) seharusnya menyediakan jasa audit tambahan yakni audit syariah secara komperhensif pada lembaga bisnis syariah (Febrian 2019).

Dalam praktiknya, pengawasan sekaligus audit syariah di Indonesia merupakan tanggung jawab Dewan Pengawas Syariah (DPS) bukan auditor syariah, padahal belum tentu DPS itu paham proses auditing syariah, akuntansi syariah dan lain-lain. Pemain kunci yang terlibat dalam audit syariah dalam sebuah entitas dengan perannya masing-masing yaitu auditor eksternal, Dewan Pengawas Syariah, auditor internal, komite audit dan divisi tata kelola (Izzatika and Lubis 2016).

Audit syariah pada jasa keuangan Islam memiliki arti akumulasi dan evaluasi bukti untuk menentukan dan melaporkan tingkat kesesuaian antara informasi dan kriteria yang telah ditetapkan untuk tujuan kesesuaian syariah. Audit harus dilakukan oleh seorang yang kompeten dan independen di bidangnya. Untuk melakukan kegiatan audit, harus ada informasi dalam bentuk diverifikasi dan beberapa standar (kriteria) dimana auditor dapat mengevaluasi informasi. 
Informasi didapat dan diambil dari semua lini. Auditor syariah melakukan audit pada dua tujuan informasi objektif (misalnya informasi keuangan pembagian keuntungan) dan informasi subjektif (informasi syariah) untuk memastikan kesesuaian syariah bank syariah (Wardayati and Wahid 2016).

\section{Kompetensi Auditor Syariah}

Adanya ketimpangan kompetensi auditor syariah di Indonesia dikarenakan oleh kehadiran entitas syariah di Indonesia tergolong masih baru, sehingga sumber daya manusia belum mampu memenuhi kebutuhan industri saat ini sehingga dewan pengawas syariah banyak direkrut dari background ulama dan dari faktor kharisma serta kepopulerannya di tengah masyarakat, bukan karena keilmuannya di bidang akuntansi, keuangan dan syariah (Izzatika and Lubis 2016).

Di sisi lain, untuk menambah jumlah sumber daya manusia di bidang audit terkhusus audit syariah, sekolah profesi untuk auditor juga ditujukan untuk menciptakan sumber daya manusia yang kompeten di bidang audit syariah. Sekolah profesi untuk auditor ini diharapkan mampu meningkatkan sumber daya manusia yang ada bukan hanya dari segi kuantitas saja, namun juga dari segi kualitas juga harus ditingkatkan.

Pada praktiknya di lapangan pada saat ini, kompetensi auditor syariah perbankan syariah tidak jauh berbeda dengan kompetensi auditor syariah pada sektor usaha yang lainnya. Masih sedikit yang memiliki kompetensi untuk menjadi auditor syariah perbankan syariah di mana seorang auditor syariah perbankan syariah harus memiliki kompetensi akuntansi dan kompetensi terkait syariah yang mencakup fiqh mualamah, ushl fiqh, qawaid fiqh, serta ayat dan hadits tentang ekonomi.

Kompetensi adalah sebuah kecakapan dan kemampuan dalam menjalankan suatu pekerjaan atau profesinya. Orang yang kompeten berarti orang yang dapat menjalankan pekerjaannya dengan kualitas hasil yang baik. Menurut Izzatika and Lubis (2016), kompetensi yang harus dimiliki auditor syariah adalah sebagai berikut: (a) Memiliki keterampilan, sikap dan pengetahuan di bidang akuntansi atau auditing. (b) Memiliki pengetahuan syariah terkait prinsip dan hukum Islam, khususnya pada fiqh muamalat. (b) Memiliki pemahaman yang kuat tentang As-Sunnah dan ilmu fiqh Islam seperti ushul figh. (c) Memahami standar akuntansi internasional yang diadopsi dengan standar akuntansi dan auditing yang berlaku di dalam wilayah nasional. Serta standar yang diadopsi oleh negaranegara muslim lain jika mereka ingin bekerja di negara lain yang telah menerapkan audit syariah. (d) Kefasihan dalam berbahasa Arab dan Inggris. (e) Memiliki pemahaman dengan pengetahuan yang baik dalam bidang keuangan dan bisnis. (f) Memahami teori dan praktik manajemen. (g) Memiliki akhlak yang baik, berwibawa, mampu berpendapat tentang ketentuan dan tujuan syariah.

Adapun kompetensi yang harus dimiliki dan dikuasai oleh para auditor syariah perbankan syariah secara keseluruhan yaitu: (1) Pengetahuan (Knowledge), Auditor syariah pada perbankan syariah harus memiliki pengetahuan di bidang audit dan syariah. Pengetahuan yang dimaksudkan adalah pengetahuan umum dan pengetahuan spesifik. Pengetahuan umum berkaitan dengan ilmu-ilmu yang didapatkan selama berada pada pendidikan formal mencakup: perbankan syariah, fiqh muamalah, Auditing, perbankan konvensional, 
manajemen risiko, matematika, akuntansi bisnis, hukum-hukum terkait, internal control, dan Pemetaan risiko. Sedangkan pengetahuan spesifik adalah ilmu-ilmu yang didapatkan dari pelatihan-pelatihan tambahan. Auditor syariah harus memiliki lima pengetahuan (knowledge) yang dijelaskan dalam common body of knowledge (CBOK) (Ali et al. 2015). Kelima pengetahuan tersebut meliputi: (a) Pengetahuan audit, auditor memahami bagaimana proses dan prosedur audit dalam perbankan syariah tersebut berlaku dan dijalankan. Seorang auditor harus memiliki pengetahuan yang memadai dalam profesinya untuk mendukung pekerjaannya dalam melakukan pemeriksaan dan pengawasan. Auditor yang memiliki banyak pengetahuan tentang kekeliruan akan lebih ahli dalam melaksanakan tugasnya terutama untuk membedakan antara kesalahan dengan kecurangan (fraud) yang berakibat terjadinya salah saji (misstatement) dalam pelaporannya. Oleh karena itu, auditor harus memiliki pengetahuan yang memadai untuk menghadapi permasalahan seperti itu. (b) Etika profesi, auditor memahami dan menerapkan kode etik dalam melaksanakan audit. Auditor harus memahami standar etika karena auditor syariah memiliki posisi sebagai orang yang dipercaya dan akan menghadapi kemungkinan benturan-benturan kepentingan. Pemahaman auditor syariah terhadap kode etik yang berlaku berfungsi untuk mempertahankan diri dari godaan-godaan dalam pengambilan keputusan yang sulit. Jika auditor tidak memahami kode etik, maka kemungkinan akan terjadi pelanggaran terhadap komitmen pada prinsip-prinsip etika yang dianut oleh profesi. Oleh karena itu, auditor syariah harus selalu menjaga kewaspadaannya terhadap godaan dan tekanan yang mampu membawanya ke dalam pelanggaran prinsip-prinsip etika secara umum dan etika profesi sehingga auditor syariah mampu untuk mengambil keputusan dan tindakan yang tepat. (c) Fraud awareness, auditor syariah mampu mendeteksi di mana letak kecurangan (fraud) terjadi. Selain itu auditor syariah harus mampu membedakan antara kesalahan (error) atau kesalahan (fraud) yang terjadi. Auditor juga harus dapat menciptakan suatu sistem untuk mencegah terjadinya kecurangan (fraud). Beberapa kasus akibat kurangnya pengawasan yang dilakukan oleh auditor syariah adalah adanya pembiayaan fiktif sebesar 1,1 triliun rupiah pada salah satu perbankan syariah di Indonesia pada tahun 2018. Kasus selanjutnya adalah adanya penipuan dan penggelapan dana sebesar 7,5 miliar rupiah yang dilakukan oleh seorang petinggi bank syariah di Jakarta pada November 2015, dan kasus pencucian uang sebesar 12,26 miliar rupiah oleh mantan petinggi bank syariah di Papua pada Mei 2017. Beberapa kasus tersebut merupakan akibat lemahnya internal kontrol yang dilakukan oleh auditor syariah. Hal tersebut tentunya berakibat pada munculnya kecurangan-kecurangan oleh para oknum di dalam perbankan syariah itu sendiri. Oleh karena itu, auditor syariah harus memiliki pemahaman lebih pada aspek fraud awreness untuk mendeteksi sedini mungkin kemungkinan terjadinya fraud dan menciptakan sistem untuk mencegah terjadinya fraud. (d) Penguasaan standar audit syariah, auditor syariah menguasi standarstandar apa saja yang berlaku dan harus menerapkannya dalam pengawasan dan pemeriksaan pada perbankan syariah. Auditor syariah harus memahami standar pelaksanaan fungsi audit intern yang dikeluarkan oleh Bank Indonesia sebagai regulator dan menerapkannya pada perbankan syariah yang diawasi dan diperiksanya. Sebagai contohnya, auditor syariah harus memahami peraturan Bank Indonesia Nomor 13/23/PBI/2011 tentang Penerapan Manajemen Risiko 
bagi Bank Umum Syariah dan Unit Usaha Syariah. (e) Memahami jenis industri atau perusahaan, auditor paham pada sektor apa perusahaan itu berjalan sehingga auditor tahu peraturan-peraturan apa saja yang harus diterapkan. Auditor juga harus memahami di mana letak kelebihan dan kekurangan industri tersebut sehingga dapat mengoptimalkan kelebihan yang dimiliki dan mengatasi kekurangan yang ada untuk mewujudkan tujuan perusahaan.

Selain kelima pengetahuan di atas, dibutuhkan SDM yang mampu untuk berbagi pengetahuan yang dia miliki dengan orang atau kelompok lain. Hal ini hanya mungkin terjadi jika dibagikan oleh orang yang mampu dan diterima oleh orang yang mau dengan tujuan untuk menjaga dan memelihara tingkat pengetahuan SDM yang ada pada perbankan syariah. Auditor syariah perbankan syariah juga harus memiliki pengetahuan yang cukup mengenai fiqh muamalah dan ushul fiqh. Kompetensi auditor syariah perbankan syariah harus melampaui atau lebih dari kompetensi normal yang dibutuhkan untuk audit syariah pada sektor-sektor lain.

(2) Keterampilan (Skill), auditor harus mampu untuk menerapkan pengetahuan yang telah dia dapatkan, baik itu pengetahuan yang didapatkan dari pendidikan formal maupun dari pelatihan-pelatihan yang dia ikuti. Auditor juga harus tahu cara untuk menyelesaikan tugas yang diterima dengan efektif dan efisien. Auditor harus mampu menghadapi berbagai masalah yang ada dan dapat mencari solusi dari permasalahan tersebut. Auditor juga harus bisa berfikir kritis dan kreatif. Selain itu, auditor dengan kemampuan berkomunikasi dalam berbagai bahasa dan memiliki adaptasi yang cepat terhadap hal yang baru akan memiliki nilai tambah. Dijelaskan dalam common body of knowledge (CBOK) dalam (Ali et al. 2018), keterampilan dibagi menjadi dua kelompok: (a) Technical Skills (Keterampilan Teknis), keterampilan ini mencakup aspek bagaimana auditor dapat memahami bisnis, analisis risiko dan penilaian kontrol, identifikasi tipe kontrol, dan tata kelola perusahaan. (b) Behavioral Skills (Perilaku), keterampilan ini mencakup aspek tingkat percaya diri seorang auditor, bagaimana objektivitas penilaian seorang auditor, keterampilan berkomunikasi, dan etika seorang auditor. Kedua keterampilan ini harus dimiliki oleh seorang auditor syariah perbankan syariah kerena kedua kelompok keterampilan tersebut saling menunjang antara satu dengan lainnya. Selain harus memiliki keterampilan teknis yang memadai, auditor syariah juga harus memiliki perilaku yang baik.

(3) Karakteristik Khusus (Special Characteristic), karakteristik khusus adalah kompetensi auditor yang mengacu pada perilaku individu di luar dari behavioral skills. Karakteristik khusus mencakup pada aspek tanggung jawab etis seorang auditor, motivasi diri, integritas seorang auditor, harga diri, manajemen diri, dan profesionalisme. Selain itu, aspek terpenting yang harus dimiliki oleh seorang auditor syariah perbankan syariah adalah karakter ke-Islaman. Karena dengan karakter ke-Islaman, seorang auditor akan lebih bertanggung jawab dan berintegritas karena dia hanya takut kepada Allah SWT dalam melaksanakan tugasnya. Seorang auditor yang memiliki karakter keislaman akan merasa setiap pekerjaan yang dilakukannya selalu berada dalam pengawasan Allah dan akan dipertanggungjawabkan di akhirat kelak sehingga dia takut untuk melakukan kecurangan $($ fraud $)$. Karakter ke-Islaman inilah yang harus dimiliki oleh seorang auditor syariah pada perbankan syariah karena tanpa karakter keislaman, kompetensi-kompetensi yang lainnya akan kurang bermakna. 
Ketiga kompetensi tersebut yang harus dimiliki oleh seorang auditor syariah perbankan syariah. Sebab, kompetensi tersebut menjadi kunci untuk memaksimalkan peran dan kompetensi auditor syariah untuk menunjang kinerja Perbankan Syariah yang saat ini masih kurang optimal dalam menjalankan tugasnya untuk mengawasi kegiatan operasional perbankan syariah dikarenakan beberapa isu atau kendala yang ada. Untuk menunjang kinerja Perbankan Syariah, auditor syariah perbankan syariah selain harus memiliki kompetensi tersebut juga harus memiliki kompetensi yang sama atau bahkan melampaui kompetensi Dewan Pengawas Syariah yang ada.

Langkah-langkah untuk menunjang kompetensi auditor syariah, dapat dibedakan menjadi dua kelompok. Yakni kelompok auditor yang berlatar belakang non-background dan kelompok auditor yang memang berlatar belakang akuntansi ataupun syariah. Langkah-langkah untuk menunjang kompetensi auditor syariah dari latar belakang non-background salah satunya dengan mengambil program pendidikan S1 sampai S3 terkait akuntansi syariah dan hukum ekonomi syariah. Selanjutnya langkah untuk latar belakang yang non-background ini juga bisa mengikuti langkah yang memiliki background akuntansi atau syariah yang merujuk pada penelitian (Dewi and Sawarjuwono 2019), di antaranya: (1) Mengikuti ujian sertifikasi akuntansi umum dan syariah, baik sertifikasi yang disediakan oleh IAI, AAOIFI, ataupun Lembaga lainnya. (2) Mengikuti Shariah Audit in Islamic Finance Workshop. Kegiatan ini untuk membahas mengenai beberapa hal, di antaranya yaitu kerangka kerja untuk review, audit, dan tata kelola syariah, perkembangan dari review, audit, dan tata kelola syariah yang ditinjau menggunakan current state analysis, standar syariah, peran dewan syariah dalam membuat regulasi, struktur, proses, dan pelaporan review serta audit syariah, dan studi kasus yang berhubungan dengan kegiatan audit syariah. (3) Mengikuti Shariah Audit Certificate Course. Program ini adalah program kursus bagi auditor syariah. Tidak berbeda jauh dengan program kursus untuk auditor syariah lainnya. Shariah audit certification course ini juga memberikan materimateri seputar audit syariah. beberapa di antaranya yaitu, teori keuangan dan bank syariah, konsep dasar audit, standar audit AAOIFI, regulasi mengenai kepatuhan syariah, tata kelola LKS, prosedur audit syariah. Ketika hal yang disebutkan di atas telah diikuti, auditor-auditor yang sudah memiliki penunjang kompetensi tersebut maka dapat menjadi satu dengan membentuk suatu kumpulan yang akan dibahas selanjutnya.

\section{Peran Auditor Syariah}

Peranan Auditor Syariah menurut Malahayatie (2018), sangat tergantung pada kompetensinya. Kompetensi dapat diklasifikasikan sebagai dimensi perilaku yang berhubungan dengan pekerjaan yang unggul. Kinerja di mana orang-orang tertentu melakukan lebih baik daripada yang lain. Selain itu, kompetensi juga terkait dengan keterampilan teknis, keterampilan dan pengetahuan untuk melakukan pekerjaan terutama pekerjaan dengan unsur profesional. Bahkan, kompetensi dapat generik atau organisasi tertentu. Kompetensi merupakan kombinasi dari atribut yang relevan seperti pengetahuan, keterampilan dan sikap sebagai dasar untuk mengukur kompetensi umum auditor.

Lulusan akuntansi masa depan untuk memahami penerapan standar yang berbeda dalam dunia akuntansi Islam sebagaimana standar yang berbeda telah 
diadopsi secara berbeda oleh berbagai negara-negara muslim yang berbeda. Lingkungan bisnis memberikan pengaruh pada pilihan standar akuntansi di negara-negara Muslim. Para sarjana harus memahami standar akuntansi Internasional serta standar yang di adopsi oleh negara-negara Muslim lain, jika ingin bekerja di negara lain. Pendidikan tinggi didesak untuk memulai program dan pelatihan baru bagi bank syariah. Saat ini ada kebutuhan yang kuat untuk pelatihan yang tepat pada konsep syariah karena sebagian besar petugas bank yang dilatih dari latar belakang konvensional. Karena audit syariah saat ini masih dilakukan oleh auditor internal, sebagian besar auditor syariah di bank syariah tidak memiliki pengalaman dan belum professional atau belum memiliki kualifikasi akademis baik di perbankan syariah.

\section{Pembentukan Asosiasi Khusus Auditor Syariah Untuk Menunjang Kinerja Perbankan Syariah}

Di Indonesia sendiri sering kita jumpai di berbagai artikel dan penelitian yang menyebutkan masalah-masalah dalam auditing syariah seperti kurangnya tenaga auditor syariah, tidak adanya lembaga independen auditing syariah, tidak adanya standar baku yang menjadi acuan audit syariah. Sehingga, praktik audit syariah yang ideal di Indonesia adalah sebagai berikut: (1) Dewan Pengawas Syariah (DPS) bertindak mengawasi penerapan fatwa di lembaga bisnis syariah dan melakukan shariah review terkait produk dan kegiatan yang dilakukan oleh lembaga bisnis syariah saja dengan meneliti hasil laporan audit syariah, yang mengaudit laporan keuangan, audit kepatuhan operasional syariah, dan audit lembaga syariah menjadi tugas auditor syariah (internal dan eksternal) (Prabowo and Jamal 2017). (2) Lembaga audit syariah harus berdiri sendiri (independen) baik itu milik pemerintah maupun swasta memberikan jasa tambahan berupa jasa audit syariah (Febrian 2019). (3) Setiap lembaga bisnis syariah diharuskan membentuk fungsi audit syariah internal sendiri, supaya tujuan syariah bisa berjalan dengan optimal (Dewi and Sawarjuwono 2019). (4) Ruang lingkup audit syariah yang meliputi laporan keuangan (termasuk Islamic Social Report dan CSR), aktivitas ekonomi, kinerja, pengaruh sosial dan lingkungan, SDM, kesyariahan produk, dan lain sebagainya (Mardiyah and Mardian 2015). (5) Dibuatkan standar audit syariah yang baku seperti Standar Umum (General Standards), Standar Pekerjaan Lapangan (Standards of Field Work), dan Standar Pelaporan (Standards of Reporting) (Febrian 2019). (6) Tersedianya kerangka kerja audit (audit framework) yang didasarkan pada aturan kegiatan lembaga bisnis syariah yang berisikan prosedur pelaksanaan dan tugas auditor syariah secara jelas dengan menyertakan aspek religiusitas (Farida and Dewi 2018). (7) Audit syariah harus memastikan kebenaran, keadilan dan relevansi laporan keuangan yang diterbitkan manajemen dan memastikan bahwa manajemen melakukan tugasnya sesuai dengan hukum dan prinsip syariah serta tujuan syariah (Kooskusumawardani and Birton 2016). (8) Auditor syariah, baik itu auditor internal maupun ekternal harus memiliki kompetensi, pengetahuan dan pemahaman mengenai akuntansi syariah, fiqh muamalah, audit syariah, manajemen keuangan syariah dan proses audit secara terstruktur dalam melakukan shariah complience test (Izzatika and Lubis 2016). (9) Audit syariah dilakukan sepanjang tahun, tidak hanya dilakukan pada saat-saat tertentu saja. Audit syariah harus dilakukan secara menyeluruh oleh semua lembaga atau perusahaan 
melakukan kegiatan bisnis berlandaskan syariah, mulai dari perhotelan syariah, bank syariah, rumah sakit Islam, rumah makan halal, dan lain-lain (Febrian 2019).

Dalam praktiknya audit syariah sekaligus pengawasan audit syariah di Indonesia masih sebagai pelengkap dari proses audit dikarenakan audit syariah masih menjadi tanggung jawab dari Dewan Pengawas Syariah (DPS) bukan auditor syariah. Sedangkan untuk praktik audit syariah yang ideal di Indonesia salah satunya adalah berdirinya lembaga audit syariah secara independen tanpa di bawah pengawasan Dewan Pengawas Syariah (Febrian 2019).

Berdasarkan pembahasan sebelumnya, dapat dipertimbangkan untuk mulai membentuk suatu asosiasi khusus guna membantu kinerja Perbankan Syariah. Penjelasan tersebut didukung oleh pendapat Karim (2009), bahwa industri perbankan syariah harus memiliki auditor syariah untuk memastikan dan memeriksa transaksi keuangan perbankan agar sesuai syariah. hal tersebut tak bisa diserahkan sepenuhnya ke dewan pengawas syariah (DPS). Pasalnya, peran dan fungsi DPS di suatu lembaga keuangan syariah yang memang mempunyai keahlian dan kompetensi, khusus untuk shariah compliance, berbeda dengan auditor yang fokus pada pemeriksaan keuangan bank. DPS berfungsi mengawasi produk dan transaksi yang dilakukan perbankan agar sesuai dengan prinsip syariah. Ada missing link di sana karena belum ada auditor yang khusus menangani hal itu. Di bank syariah saat ini, pelaksanaan audit telah dilakukan auditor biasa. Untuk penyiapan SDM auditor syariah tersebut, dapat dilakukan melalui kerja sama dengan melibatkan Dewan Syariah Nasional MUI untuk memberikan sertifikat auditor atau asosiasi auditor.

Asosiasi Auditor Syariah berbeda dengan Asosiasi Auditor Umum, dimana asosiasi auditor umum lebih berfokus pada audit konvensional, sedangkan asosiasi auditor syariah sepenuhnya membahas terkait audit yang berprinsip syariah. Asosiasi auditor syariah ini juga mendukung peranan DSN MUI. Asosiasi tersebut nantinya bertanggung jawab untuk mengawasi aspek kepatuhan segala aktivitas yang ada pada perbankan syariah tersebut yang berkoordinasi dengan auditor perbankan syariah. Dengan adanya asosiasi khusus di bawah OJK, tugas auditor Perbankan Syariah nantinya akan lebih mudah karena terdapat syariah yang secara praktiknya sudah mengawasi kegiatan perbankan syariah secara intensif. Asosiasi ini akan melaporkan hasil pengawasannya kepada OJK.

Pada struktur organisasi, posisi asosiasi khusus ini nantinya akan berada langsung di bawah OJK namun tetap berkoordinasi dengan perbankan syariah. Dengan posisinya yang berada tepat di bawah OJK, membuat asosiasi khusus ini menjadi lebih independen. Asosiasi khusus ini bertugas untuk membantu tugas OJK dan mendukung peranan DSN MUI yang kurang optimal dalam melaksanakan tugasnya untuk mengawasi aktivitas perbankan syariah yang berkaitan dengan sharia compliance.

\section{KESIMPULAN}

Kompetensi yang harus dimiliki auditor syariah meliputi, Pertama, pengetahuan yang mencakup bidang perbankan syariah, fiqh mualamah, teori auditing, perbankan konvensional, manajemen risiko, matematika, akuntansi bisnis, hukum-hukum terkait, internal kontrol, dan pemetaan risiko. Pengetahuan spesifik mencakup pengetahuan audit, etika profesi, fraud awareness, penguasaan 
standar audit syariah, dan memahami jenis industri atau perusahaan. Kedua, keterampilan akuntansi dan auditing yaitu: memahami standar akuntansi internasional yang diadopsi dengan standar akuntansi dan auditing yang berlaku di dalam wilayah nasional, serta standar yang diadopsi oleh negara-negara muslim lain jika mereka ingin bekerja di negara lain yang telah menerapkan audit syariah; memiliki pemahaman dengan pengetahuan yang baik dalam bidang keuangan dan bisnis; memahami teori dan praktik manajemen; dan sebagainya. Ketiga, karakteristik khusus meliputi tanggung jawab etis, integritas, harga diri, manajemen diri, dan profesionalisme. Dan yang paling utama yang wajib dimiliki oleh seorang auditor perbankan syariah adalah karakter keislaman, karena dengan karakter keislaman, seorang auditor syariah akan selalu merasa setiap pekerjaannya diawasi oleh Allah SWT dan akan dipertanggungjawabkan di akhirat kelak sehingga dia takut untuk melakukan kecurangan (fraud). Ketiga kompetensi tersebut menjadi kunci untuk memaksimalkan peran dan kompetensi auditor syariah untuk menunjang kinerja Perbankan Syariah.

Peran auditor syariah antara lain sebagai auditor independen, internal auditor, dan dewan pengawas syariah. Sedangkan peran auditor eksternal tidak hanya melakukan audit keuangan melainkan juga melakukan shariah compliance test untuk memastikan kepatuhan syariah dari perusahaan atau LKS. Internal auditor dapat menjalankan fungsi audit syariah yang bertujuan untuk memastikan bahwa pengendalian internal telah berjalan dengan baik dan sesuai dengan prinsip syariah. DPS memiliki fungsi untuk merumuskan kebijakan dan pedoman yang harus diikuti oleh manajemen dalam melakukan kegiatan bisnis serta memberikan persetujuan atas produk yang akan dikeluarkan dan melakukan penilaian syariah. Selain itu, auditor syariah juga berperan dalam melakukan shariah compliance test untuk memastikan kepatuhan shariah entitas Lembaga Keuangan Syariah.

Penelitian ini memiliki keterbatasan terutama dalam hal data karena masih sebatas studi literatur dan belum ditemukan studi lapangan untuk mengkonfirmasi kondisi realita di industri maupun regulasi. Oleh sebab itu untuk penelitian selanjutnya penting kiranya untuk melakukan studi lapangan, sehingga pembahasan lebih komprehensif antara teori ideal, praktek dan peraturan ada. Untuk industri dan regulasi, hendaknya mulai dpertimbangkan dalam pembentukan asosiasi khusus auditor syariah sehingga lebih fokus dalam mendukung kinerja lembaga keuangan syariah.

\section{DAFTAR PUSTAKA}

Akbar, Taufik, Sepky Mardian, and Syaiful Anwar. 2015. "Mengurai Permasalahan Audit Syariah dengan Analytical Network Process (ANP)". Jurnal Akuntansi Dan Keuangan Islam 2 (2): 101-123. https://doi.org/10.35836/jakis.v3i2.32.

Ali, Nor Aishah Mohd., Zakiah Muhammadun Mohamed, Shadida Shahimi and Zurina Shafii. 2015. "Competency of Shariah Auditors in Malaysia: Issues and Challenges". Journal of Islamic Finance 4 (1): 22-30.

Ali, Nor Aishah Mohd., Shahida Shahimi, and Zurina Shafii. 2018. "Knowledge, Skills and Characteristics Requirements for Shari'ah Auditors". Asian Journal of Accounting and Governance 9: 171-185. 
https://doi.org/10.17576/ajag-2018-09-15.

Ardi, Muhammad. 2017. "Peran Audit Internal Terhadap Pelaksanaan Good Governance di Perbankan Syariah". DIKTUM: Jurnal Syariah Dan Hukum 15 (2): 169-176. https://doi.org/10.35905/diktum.v15i2.433.

Azzarqa, and Syamsul Hadi. 2017. "Audit dan Tata Kelola Lembaga Keuangan Syariah”. Jurnal Hukum Islam dan Bisnis 9 (2): 170-181.

Baehaqi, Ahmad, and Suyanto. 2018. "Audit Internal Lembaga Keuangan Syariah Dalam Perpektif Al-Hisbah”. Jurnal Riset Keuangan Dan Akuntansi 4 (2): 15-24. https://doi.org/10.25134/jrka.v4i2.1694.

Carolita, Metha Kartika, and Shiddiq Nur Rahardjo. 2012. Pengaruh Pengalaman Kerja, Independensi, Objektifitas, Integritas, Kompetensi, Dan Komitmen Organisasi Terhadap Kualitas Hasil Audit (Studi pada Kantor Akuntan Publik di Semarang). Skripsi Universitas Diponegoro.

Dewi, Sari Kusuma, and Tjiptohadi Sawarjuwono. 2019. "Tantangan Auditor Syariah : Cukupkah Hanya dengan Sertifikasi Akuntansi Syariah?”. Jurnal Dinamika Akuntansi Dan Bisnis 6 (1): 17-28. http://dx.doi.org/10.24815/jdab.v6i1.10903.

Farida, and Veni Soraya Dewi. 2018. "Kompetensi Auditor dan Shariah Compliance Terhadap Praktik Audit Syariah". Jurnal Analisis Bisnis Ekonomi $16 \quad$ (1): 45-52. https://doi.org/10.31603/bisnisekonomi.v16i1.2130.

Fauzi, Ahmad, and Ach Faqih Supandi. 2019. "Perkembangan Audit Syariah di Indonesia (Analisis Peluang Dan Tantangan)". ISTIQRO: Jurnal Hukum Islam, Ekonomi Dan Bisnis 5 (1): 24-35. https://doi.org/10.30739/istiqro.v5i1.339.

Febrian, Dodi. 2019. "Problematika Audit Syariah Pada Lembaga Bisnis di Indonesia". ISTIQRO: Jurnal Hukum Islam, Ekonomi Dan Bisnis 5 (2): 154-164. https://doi.org/10.30739/istiqro.v5i2.427.

Izzatika, Nadia Farhana, and Ahmad Tarmidzi Lubis. 2016. "Isu dan Tantangan Kompetensi Dewan Pengawas Syariah di Indonesia”. Jurnal Akuntansi $\begin{array}{lllll}\text { Dan Keuangan } & \text { Islam } & \text { 147-168. }\end{array}$ https://doi.org/10.35836/jakis.v4i2.24.

Jesika, Maria Ludya, Ramot Simanjuntak, and Salmon Sihombing. 2015. "Independensi dan Tanggung Jawab Auditor dan Pengaruhnya Terhadap Opini Auditor (Studi Kasus pada Kantor Akuntan Publik di Wilayah Jakarta Selatan)". Buletin Ekonomi: Kajian Manajemen, Akuntansi, Pajak dan Ekonomi 19 (3): 1-10.

Karim, Adiwarman A. 2009. Bank Syariah Perlu Auditor Khusus Syariah. MES. http://www.ekonomisyariah.org/id/4138/bank-syariah-perlu-auditorkhusus-syariah/.

Kooskusumawardani, Nadia, and M. Nur A. Birton. 2016. "Pengaruh Kompetesi dan Independensi Auditor Dalam Pelaksanaan Sharia Compliance di Lembaga Keuangan Syariah (LKS)". Simposium Nasional Akuntansi XIX: $1-20$.

http://mvdw.org/images/arsip/akuntansi/Nadia_Kooskusumawardani_M_ Nur_A_Birton.pdf

Malahayatie. 2018. "Peranan Auditor Syariah Pada Sistem Jaminan Halal di Bank Syariah (Studi Kasus Perbankan Syariah Indonesia)". JESKaPe: Jurnal 
Ekonomi Syariah, Akuntansi dan Perbankan 2 (2): 121-157.

Mardian, Sepky. 2015. "Tingkat Kepatuhan Syariah di Lembaga Keuangan Syariah". Jurnal Akuntansi Dan Keuangan Islam 3 (1): 57-68. https://doi.org/10.35836/jakis.v3i1.41.

Mardiyah, Qonita, and Sepky Mardian. 2015. "Praktik Audit Syariah di Lembaga Keuangan Syariah Indonesia”. Akuntabilitas: Jurnal Ilmu Akuntansi 8 (1): 1-17. https://doi.org/10.15408/akt.v8i1.2758.

Minarni. 2013. "Konsep Pengawasan, Kerangka Audit Syariah, dan Tata Kelola Lembaga Keuangan Syariah". La_Riba: Jurnal Ekonomi Islam 7 (1): 2940. https://doi.org/10.20885/lariba.vol7.iss1.art3.

Mulazid, Ade Sofyan. 2016. "Pelaksanaan Sharia Complience Pada Bank Syariah (Studi Kasus Pada Bank Syariah Mandiri, Jakarta)". Madania: Jurnal Kajian Keislaman 20 (1): 37-54.

Munawir, Hafidh. 2005. "Perencanaan Strategi Pengembangan Bank Syariah Di Indonesia". Jurnal Ilmiah Teknik Industri 4 (1): 41-48. http://journals.ums.ac.id/index.php/jiti/article/view/1295.

Nawal, Shahul Hameed Mohamad Ibrahim, and Maliah Sulaiman. 2009. "Shariah Auditing in Islamic Financial Institutions: Exploring The Gap Between The 'Desired' and The 'Actual'". Global Economy \& Finance Journal 2 (2): 127-137.

Nuha, Gardina Aulin. 2017. "Review Audit Dengan Perspektif Syariah". JIAI (Jurnal Ilmiah Akuntansi Indonesia) 2 (2): 1-14.

Prabowo, Bagya Agung, and Jasri Bin Jamal. 2017. "Peranan Dewan Pengawas Syariah terhadap Praktik Kepatuhan Syariah dalam Perbankan Syariah di Indonesia". Jurnal Hukum IUS QUIA IUSTUM 24 (1): 113-129. https://doi.org/10.20885/iustum.vol24.iss1.art6.

Putri, Yunita Raj Alfan, and Nur Hidayati. 2019. "Pengaruh Kompetensi dan Independensi Auditor Dalam Pelaksanaan Sharia Compliance di Lembaga Keuangan Syariah (LKS)". Jurnal Ilmiah Riset Akuntansi 8 (06): 27-48.

Riani, and Sepky Mardian. 2017. "Dinamika Kualitas Audit di Perbankan Syariah di Indonesia”. Jurnal Akuntansi Dan Keuangan Islam 5 (2): 177-194. https://doi.org/10.35836/jakis.v5i2.21.

Shafii, Z., A. Z. Abidin, S. Salleh, K. Jusoff, and N. Kasim. 2013. "Post Implementation of Shariah Governance Framework: The Impact of Shariah Audit Function Towards the Role of Shariah Committee". Middle East Journal of Scientific Research 13: 7-11.

Suginam. 2017. "Pengaruh Peran Audit Internal dan Pengendalian Intern Terhadap Pencegahan Fraud (Studi Kasus Pada PT. Tolan Tiga Indonesia). Owner: Riset Dan Jurnal Akuntansi 1 (1): 22-28.

Suryanto, Tulus. 2014. "Manajemen Laba Pada Bank Syariah di Indonesia : Peran Komite Audit Dan Dewan Pengawas Syariah". Kinerja: Journal of Business and Economics 18 (1): 90-100. https://doi.org/10.24002/kinerja.v18i1.520.

Umam, Khotibul. 2015. "Urgensi Standarisasi Dewan Pengawas Syariah dalam Meningkatkan Kualitas Audit Kepatuhan Syariah". Jurnal Perhimpunan Mahasiswa Hukum Indonesia 1 (2): 115-138.

Wardayati, Siti Maria. 2011. "Implikasi Shariah Governance Terhadap Reputasi dan Kepercayaan Bank Syariah”. Walisongo: Jurnal Penelitian Sosial 
Keagamaan 19 (1): 1-24. https://doi.org/10.21580/ws.19.1.210.

Wardayati, Siti Maria, and Abdul Muis Al Wahid. 2016. "Pandangan Institusi Keuangan Islam Terhadap Audit Syariah". Fenomena: Jurnal Penelitian 8 (2): 111-126.

Yaacob, Hisham. 2012. "Issues and Challenges of Shari'ah Audit in Islamic Financial Institutions: A Contemporary View". Proceedings of $3 \mathrm{rd}$ International Conference on Business and Economic Research: 26692679. https://dx.doi.org/10.2139/ssrn.2175700.

Yaacob, Hisham, and Nor Khadijah Donglah. 2012. "Shari'ah Audit in Islamic Financial Institutions: The Postgraduates' Perspective". International Journal of Economics and Finance 4 (12): 224-239. https://doi.org/10.5539/ijef.v4n12p224. 